\title{
Bacchus among the Blackshirts: Wine Making, Consumerism and Identity in Fascist Italy, 1919-1937
}

\author{
Brian J Griffith \\ University of California, Los Angeles, Los Angeles, California, 90095-1473, USA \\ brianjgriffith@ucla.edu
}

This article explores the way in which wine came to be viewed as a quintessentially 'Italian' beverage among Italy's middle- and upper-class households during fascism's twenty years in power. Due to significant increases in wine consumption among the labouring classes during the years immediately following the First World War, wine, as a general category of beverage, had become closely associated within the minds of many bourgeois and wealthy consumers with the country's popular taverns and saloons, alcoholism and physical and moral 'degeneration.' In response, fascist Italy's typical wine growers, merchants and industrialists worked feverishly to rehabilitate the beverage's downtrodden reputation via a series of wide-ranging public relations and collective marketing campaigns during the 1920s and 1930s. By promoting the beverage's hygienic and alimentary qualities, as well as systematically intertwining the moderate consumption of the peninsula's standardised wines with the dictatorship's nationalisation and popular mobilisation programmes, this article will show, the Industrial Wine Lobby successfully re-established 'wine's honour' and, simultaneously, recontextualised the country's typical wines as Italy's wholesome, family-friendly, 'national beverage'.

In November 1933 an extraordinary paperback appeared on the shelves of Italy's bookstores and newspaper kiosks. Titled The Art of Drinking (L'arte di bere), Umberto Notari's 'fictional essay on economics' addressed the origins of, as well as proposed various solutions to, what many contemporaries considered to be the country's burgeoning 'wine crisis'. 'Men no longer drink' wine laments the story's protagonist, the Marquis Olinto Baglia, to a group of his acquaintances. Instead of vino, the twentiethcentury man 'drinks other things' such as coffee, tea, liquor and various other types of mostly 'insalubrious' and 'foreign' beverages. 'Among our, as well as the preceding, generation', he continues, wine consumption had dropped by as much as thirty per cent. ${ }^{2}$ Such staggering losses, Baglia worryingly exclaims, were emblematic of a 'universal moroseness' which had gloomily descended over the Italian peninsula between the fin-de-siècle and the years immediately following the First World War. ${ }^{3}$ Serving as a poignant symbol of 'national degeneration', the precipitous loss of wine consumers had only exacerbated the beverage's blemished public image among middle- and upper-class connoisseurs. Instead of 'elevating the people to the highness of wine', the Marquis contends, Italy's 'millennial' beverage had been 'democratised' and 'lowered to the level of commoners'.

\footnotetext{
1 Umberto Notari, L'arte di bere: saggio di economia a romanzo (Villasanta: Soc. Anon. Notari, 1933), 44. Notari is, perhaps, most widely known for founding, along with his wife Delia, the so-called 'bible of culinary magazines', Italian Cuisine (La cucina italiana). See Emanuela Scarpellini, Food and Foodways in Italy from 1861 to the Present (New York: Palgrave Macmillan, 2016), 83.

2 Notari, L'arte di bere, 43.

3 Ibid., 44.

4 Ibid., 114
}

(C) The Author(s) 2020. This is an Open Access article, distributed under the terms of the Creative Commons Attribution licence (http://creativecommons.org/licenses/by/4.0/), which permits unrestricted re-use, distribution, and reproduction in any medium, provided the original work is properly cited. 
What was urgently required, interjects Primarosa Mathossian - one of the Baglia's invitees and, in Notari's eyes, the archetypical fascist woman - was the popularisation of a 'national taste for wine'. 'No product is closer than wine to the human soul', she contends - ostensibly convinced by the Marquis's ceaseless overtures regarding the beverage's indispensable role within the country's forthcoming national palingenesis - 'No product has more power [than wine] to transform man's spirit' 6

Notari, of course, was not alone in such concerns. Indeed, during fascism's twenty years in power (1922-45), Italy's luxury wine growers, merchants and industrialists laboured feverishly to rehabilitate the beverage's downtrodden public image among the country's privileged households. Stemming from a combination of decreasing wholesale prices for common wines and increasing hourly wages for industrial labourers during the opening decades of the twentieth century, the popular classes had gradually become, in the anxious words of one contemporary, 'the great mass of drinkers in Italy'. ${ }^{7}$ By the early 1920s, therefore, wine, as a general category of beverage, was closely intertwined within the minds of many middle- and upper-class consumers with the country's popular taverns and saloons, alcoholism and physical and moral degeneration among the labouring masses.

In responding to these challenges, the country's pro-wine campaigners pursued a variety of ambitious and wide-ranging public relations and collective marketing campaigns, which were intended to re-establish 'wine's honour' and recontextualise the peninsula's 'standardised' or 'typical' wines as interwar Italy's wholesome, family-friendly 'national beverage'. ${ }^{8}$ Informally led by the indomitable Arturo Marescalchi, to whom The Art of Drinking was warmly dedicated, the Industrial Wine Lobby (IWL) aggressively underscored wine's purported 'alimentary and hygienic virtues' by harshly distinguishing between 'genuine' Italian wines and other categories of alcoholic beverages. ${ }^{9}$ Partnering with some of Italy's most outspoken 'medical celebrities', the IWL's pro-wine publicity campaigns were intended to convince the 'educated classes' of the myriad benefits of moderate wine consumption. ${ }^{10}$ In addition to encouraging Italians to substitute their consumption of foreign or 'exotic' beverages with the peninsula's luxury wines, wine lobbyists reached out, specifically, to Italian housewives by promoting the quintessentially Italian 'art of drinking.' ${ }^{11}$ Wholly conscious of the influences of women's preferences within the bourgeois household, the pro-wine lobby sought to promulgate what Marescalchi coined as a 'wine education' among middle- and upper-class Italian women. ${ }^{12}$ In shaping the 'female palate', the IWL hoped to transform Italian women into loyal wine consumers themselves and, equally as significant, indirectly influence the tastes and habits of their immediate family members and friends. ${ }^{13}$ The peninsula's public spaces of consumption, too, fell under the purview of wine lobbyists' scrutiny. In 1929 pro-wine campaigners launched the 'the rebirth of the wine tavern'. ${ }^{14}$ Filled with bright streams of hygienic daylight, tasteful furniture and stimulating embellishments, fascist Italy's 'rehabilitated' osterie would, wine lobbyists anticipated, reintroduce middle-class and wealthy consumers to the country's 'temple' of wine consumption. ${ }^{15}$ In the early 1930s Benito

5 Ibid., 185.

6 Ibid., 65.

7 David Levi-Morenos, 'Vino e alcoolismo nell'economia nazionale: III. L'intervento dello Stato', Critica sociale (1-15 Oct. 1920), 297.

8 Article 1 in 'Disposizioni per la difesa dei vini tipici', n. 497, Gazzetta Ufficiale (7 Mar. 1924); Marescalchi, 'Una buona disposizione', Il commercio vinicolo (8 Aug. 1931), 1.

9 'Il comitato di azione per la difesa del vino', Enotria (Oct. 1923), 629; 'La “Casa del Vino", Enotria (Mar. 1924$), 68$.

10 Marescalchi, 'La riabilitazione del vino', Il commercio vinicolo (1 Dec. 1934), 1; Notari, L'arte di bere, 113.

11 “'L’Ora della merenda”: Il successo del trattenimento vinicolo a Gardone', Il commercio vinicolo (1 June 1935), 1; 'Riunioni vinicole e propaganda', Il commercio vinicolo (18 May 1935), 1; G.M., 'L'arte del bere', Enotria (Feb. 1931 ), 57.

12 Marescalchi, 'L'educazione vinicola', Il commercio vinicolo (24 May 1930), 1.

13 Notari, L'arte di bere, 77.

14 RUSTICO, 'La rinascita dell'osteria', Il Popolo d'Italia (25 Oct. 1930), 3.

15 Benito Mussolini, Discorso dell'Ascensione: il regime fascista per la grandezza d'Italia (Roma: Libreria del Littorio, 1927), 13; Marescalchi, 'La riabilitazione delle osterie', Il commercio vinicolo (8 Nov. 1930), 1; Guido Marangoni, 'L'osteria nel mondo: la nuova osteria “a l'aria valtriumplina” di Brescia', Enotria (June 1933), 428. 
Mussolini's dictatorship launched a wide range of interconnected popular mobilisation campaigns which aimed to stimulate a nationally focused, self-sufficient economy and, more broadly, a widespread feeling of collective belonging among Italians. In the wake of these campaigns, the IWL encouraged Italian sightseers and connoisseurs to 'get to know [their] country better' by exploring the peninsula's bucolic countryside via gastronomic sojourns and 'oenological itineraries'. ${ }^{16}$ Culminating with Siena's Exhibition Market of Typical Italian Wines and the National Wine Truck in 1933 and 1934, respectively, wine lobbyists' turismo themed collective marketing campaigns visually, as well as spatially, conjoined the consumption of Italy's luxury wines with Italian national identity.

This article explores the way in which vino came to be viewed as an 'Italian' beverage among Italy's bourgeois and upper-class households during the interwar decades. More broadly, it seeks to illuminate the various ways in which influential agro-industrial organisations co-opted, and in some cases actively shaped, the regime's 'reclamation' and mass mobilisation campaigns by promoting the consumption of their industry's foodstuffs and beverages as a 'national duty'. ${ }^{17}$ During its two decades in power, as historians of fascism have amply demonstrated, Mussolini's dictatorship sought to reshape Italians' relationships both with the Italian state and with one another by deploying 'austere dietary habits' as 'potent symbols of political allegiance and national identity. ${ }^{18}$ Indeed, by frequently associating consumer 'duties' with national 'duties', the dictatorship 'provided the thrust to create an identity and profile which was typical of an "Italian" consumer. ${ }^{19}$ While significantly expanding our understanding of the regime's impacts, or lack thereof, upon Italians' mentalités and collective practices, however, scholars of fascism have largely overlooked the inconspicuous, but nonetheless influential, roles played by intermediating agents, groups, and organisations within the shaping of the foundations of a distinctly Italian consumer consciousness and identity during the fascist ventennio. In contrast to the Duce's presumptuous claim that 'only the state can give people a sense of selfawareness', many of interwar Italy's industrial lobbying organisations, including the IWL, co-opted and manipulated the regime's campaigns for regenerating Italian bodies and behaviours in accordance with their industries' largely private commercial objectives. ${ }^{20}$ By analysing the varying ways in which typical wine growers, merchants and industrialists, in partnership with Mussolini's dictatorship, sought to rebrand the peninsula's standardised wines as the country's 'millennial' beverages, therefore, this study intends to illuminate, as well as expand our understanding of, the complex dynamics of political agency and culture-shaping power in fascist Italy.

\section{The 'Battle' against the Bottle and the Bettola}

During the first two decades of the twentieth century the demographics, as well as meanings, of wine consumption in Italy changed dramatically. Between 1880 and 1910 Italian wine production doubled by a yearly average of more than twenty million hectolitres. As a result of these increases in domestic production, wholesale prices shrank considerably, which delivered affordable common wines (vini comuni) directly into the hands of the country's popular classes. ${ }^{21}$ Such circumstances, exclaimed

16 Marescalchi, 'Prefazione', in Guida Gastronomica d'Italia (Milano: Touring Club Italiano, 1931), 6; 'Itinerari enologici', Enotria (Nov. 1934), 663.

17 Ruth Ben-Ghiat, Fascist Modernities: Italy, 1922-1945 (Berkeley: University of California Press, 2004), 4; Marescalchi, 'Ristoratori ferroviari', Il commercio vinicolo (8 Dec. 1934), 1.

18 Carol Helstosky, 'Fascist Food Politics: Mussolini's Policy of Alimentary Sovereignty', Journal of Modern Italian Studies, 9, 1 (2004), 5.

19 Scarpellini, Material Nation: A Consumer's History of Modern Italy (Oxford: Oxford University Press, 2011 ), 88.

20 Mussolini, Discorso dell'Ascensione, 79.

21 Ippolito Pestellini, Sulla difesa dei vini tipici italiani (Firenze: Tipografia di M. Ricci, 1910), 5; Giuseppe Vergone, La crisi vinicola (Napoli: Tipografia Domenico di Gennaro, 1908), 17; Marescalchi, Per lo sviluppo della industria enologica italiana (Bologna: Nicola Zanichelli, 1919), 14. Between the 1860s and the turn of the century, the phylloxera - a semimicroscopic louse which primarily feeds on the rootstocks of grapevines - devastated large swaths of vineyards in Spain, Italy and, above all, France. In an effort to protect French wine growers from the commercial impacts of the 
Alessandro Schiavi in the Italian Anti-Alcoholic Federation's 1909 study Is Alcohol a Danger for Italy? (L'alcoolismo è un pericolo per l'Italia?), amounted to an 'anarchy of wine growers', which mandated an immediate, and decisive, intervention by society's higher orders. ${ }^{22}$

The First World War only accelerated these worrisome developments. As the cost of living gradually increased, so too did the retail prices of wine, which swelled from an average of just 26 lire per hectolitre in 1914 to over 150 lire by $1919 .{ }^{23}$ Such dramatic price increases, however, were not uniformly experienced by all Italians alike. While industrial laborers' wages had more or less kept pace with the rate of wartime inflation, the salaries of white-collar professionals had sharply declined. ${ }^{24}$ Consequently, many bourgeois Italian families began purging various 'discretionary' items from their weekly budgets, including coffee, tobacco and, of course, wine and other categories of alcoholic beverages. The inflated price of wine, exclaimed one contemporary, emphasising the impacts of the cost of living crisis on Italy's middle-class households, had nearly eliminated its consumption among 'the petty bourgeoisie in the category of fixed-salaried employees' while increasing significantly among factory workers and agricultural labourers which, during the immediate post-war months and years, represented 'the great mass of drinkers in Italy. ${ }^{25}$

Such considerable shifts in the demographics of alcohol consumption, of course, vexed contemporary observers from across the country's political spectrum. Of particular concern for many were the growing numbers of popular wine taverns and saloons (osterie and bettole, respectively). 'It is well known' that certain 'excesses of violence. . . originate from the osterie', bemoaned one anonymous commentator in the 15 July 1919 issue of the popular liberal daily, Evening Courier (Corriere della Sera), where many labourers 'get drunk together on words and wine'. ${ }^{26}$ Many of these anxieties were shared by many on the political left, as well. 'We have. . something like 222 thousand bettole and similar establishments in Italy', complained the influential socialist deputy Filippo Turati in February 1921, which amounted to approximately one 'tavern for every 150 inhabitants'. ${ }^{27}$ Such alarming figures, many were convinced, required 'a strict state action' in order to both suppress the physiologically and socially destructive lifestyles and behaviours of the popular classes and, in the words of the National Secretariat against Alcoholism, Domenico Pastorello, stimulate a 'moral and civil renewal of our people. ${ }^{28}$

The Blackshirts, of course, shared many of these apprehensions regarding the 'crisis' of alcohol dependency among the country's labouring classes. On 9 April 1923, for instance, Benito Mussolini dispatched a widely publicised telegram to the Trade Union of Tavern Hosts and Diner Owners in Tivoli, just outside of Rome. In his message, which was reproduced in a handful of temperance and wine making periodicals, the prime minister praised the organisation's leadership for its decision to close the city's popular taverns, bars, and saloons on Sundays by 3pm. 'I approve it unconditionally', Mussolini exclaimed, continuing: 'yours is a beautiful gesture of discipline, dignity and civic morality'. The 'abuse of wine and liquors', the prime minister continued, signalling fascism's long-term objective

phylloxera crisis, the French government placed heavy tariffs on the importation of 'low quality' Italian wines which, in conjunction with progressively higher grape yields in Italy during the aforementioned years, led to higher quantities of common wines and, naturally, plumetting wholesale prices. See Leo A. Loubère, The Red and the White: The History of Wine in France and Italy in the Nineteenth Century (Albany: State University of New York Press, 1978), Kolleen M. Guy, When Champagne Became French: Wine and the Making of a National Identity (Baltimore: The Johns Hopkins University Press, 2007) and George Gale, Dying on the Vine: How Phylloxera Transformed Wine (Berkeley: University of California Press, 2011).

22 Federazione Antialcoolista Italiana, L'alcoolismo è un pericolo per l'Italia? (Milano: Società Umanitaria, 1909), xv.

23 F. Carpentieri, 'I prezzi del vino', Enotria (Jan. 1921), 15.

24 'Italy, Home Front', in Spencer C. Tucker, ed., The European Powers in the First World War: An Encyclopedia (New York: Routledge, 2013), 376.

25 Levi-Morenos, 'Vino e alcoolismo nell'economia nazionale: III. L'intervento dello Stato', 297.

26 'Il vino è un consumo di prima necessita?', Corriere della Sera (15 July 1919), 2.

27 Filippo Turati to the Chamber of Deputies, Atti parlamentari (22 Feb. 1921), 7,962.

28 Levi-Morenos, 'Vino e alcoolismo nell'economia nazionale: III. L'intervento dello Stato', 297; Domenico Pastorello, 'Come si diffama l'Italia', Contro l'alcoolismo (Dec. 1923), 7. 
of 'making Italians' via hygienic socio-environmental interventions, 'must no longer corrupt and degenerate the Italian race'. Expressing his 'heartfelt sympathy' for the Tivoli Union's humble, but nonetheless significant, measures against popular alcoholism, Mussolini promised that his 'government will take account of your pioneering measures for [establishing] general order' in Italy. ${ }^{29}$

During the subsequent months Italy's soon-to-be Duce began fulfilling his promises. On 7 October 1923, only a few weeks shy of the one year anniversary of the March on Rome, the fascist-led Chamber of Deputies approved a number of 'Provisions for Combatting Alcoholism', which increased the regulatory maximum of taverns and saloons 'selling or for consuming wine, beer and any [other] alcoholic beverage' from 'one per 500 inhabitants to one per thousand inhabitants' in every municipality, effectively slashing the number of osterie, bettole and other similarly 'seedy' establishments by 50 per cent. Additionally, the regime's anti-alcoholism legislation placed an interminable moratorium on the approval of any new licenses for selling or serving alcoholic beverages - with the sole exception of those which had been acquired through 'legitimate or testamentary succession' - and constrained the hours of operation for any legally remaining wine taverns to the hours between 10am and $11 \mathrm{pm} .{ }^{30}$ Such 'hygienic actions', of course, were entirely in keeping with fascism's broader agricultural, human and cultural 'integral reclamation' (bonifica integrale) campaigns which, in Ruth Ben-Ghiat's words, aimed to 'combat degeneration and radically renew Italian society by "pulling up the bad weeds and cleaning up the soil"'. ${ }^{31}$ Between 1923 and 1927 the 'Provisions for Combatting Alcoholism' led to the closures of approximately 25,000 popular osterie in Italy - a 'surgical' intervention which, many Blackshirts believed, would contribute to the 'healing' of interwar Italian society from its 'degeneracy' and 'symptoms of decline'. ${ }^{32}$ 'Since we probably will not have another chance to get the votes of tavern keepers or their customers, as was the case in the liberal democratic Middle Ages', Mussolini pompously explained to the Chamber of Deputies during his infamous Ascension Day speech in May 1927, alluding to the dictatorship's temperance campaigns during the previous half-decade, 'we can allow ourselves the luxury of closing these outlets of cheap and damaging . . spirits' ${ }^{33}$

\section{Industrialising and Standardising Italy's Typical Wines}

This proletarianisation of wine and its consumption in post-war Italy, however, concerned more than just the country's political and intellectual establishments. Indeed, between 1919 and 1922 an irreconcilable schism began opening up between the peninsula's peasant, or common, wine growers and a bourgeoning IWL. Loosely coordinated by Milan's Italian Wine Union (Unione Italiana Vini; UIV), Italy's typical wine growers, merchants and industrialists intended to standardise and, ultimately, centralise Italian table grape cultivation and wine making under their exclusive authority and command. ${ }^{34}$ According to members of the IWL, the country's vini comuni were 'inferior' to those being produced by the peninsula's genuine, or luxury, wine growers. Unlike the latter, many pro-wine

29 'Preannuncio di misure contro l'alcoolismo', Giornale vinicolo italiano (15 Apr. 1923), 168.

30 'Disposizioni per combattere l'alcoolismo', n. 251, Gazzetta Ufficiale (25 Oct. 1923).

31 Mussolini, Discorso dell'Ascensione, 13; Ben-Ghiat, Fascist Modernities, 4.

32 Mussolini, Discorso dell'Ascensione, 15; Ben-Ghiat, Fascist Modernities, 5.

33 Mussolini, Discorso dell'Ascensione, 15.

34 Originally founded in 1895 as the Lombard Union among Wine Merchants (Unione Lombarda fra i Negozianti di Vini), the Italian Wine Union (1919-present) emerged as Italy's largest, most influential wine growing, distribution and collective marketing organisation during the immediate post-First World War years - an influence it still enjoys today. While led by six presidents between 1922 and 1938, along with a board of directors composed of some of the country's most renowned wine growers, merchants and industrialists, Marescalchi - due largely to his voluminous publications and numerous connections within both the liberal and, following the March on Rome in October 1922, fascist political establishments - remained the organisation's informal 'Duce' throughout the interwar decades. In addition to his many roles within the Industrial Wine Lobby, it should be pointed out, Marescalchi served alongside Giacomo Acerbo as Italy's Undersecretary of the Ministry of Agriculture and Forestry between 1929 and 1935 - a position he readily deployed towards the deepening of the wine making industry's ties with Mussolini's dictatorship. See Unione Italiana Vini: 1895-1957 (Milano: Unione Italiana Vini, 1957). 
campaigners frequently bemoaned, peasant wine growers lacked the state-of-the-art agricultural and fermentation equipment and, no less important, the professional experience required for producing high quality, organoleptically stable wines. 'Except for Vermouth, Marsala, some typical Piedmont wines and Chianti', lamented one industrial wine lobbyist from Tuscany in 1919, the Italian wine making industry was overburdened by 'raw, ordinary wines' which were 'destined to be processed, transformed and stored abroad'. ${ }^{35}$ Such an order of affairs, he explained, was a disgrace to Italy's 'millennial' oenological roots, which purportedly stretched back to the Etruscans, Greeks and Romans. The time had come, many wine lobbyists believed, for Italian viti-viniculture to rise, once again, like a phoenix from its ashes and claim its rightful place within both the Italian state's legislative programmes and, no less significant, the dining tables of the country's bourgeois and upper-class households. ${ }^{36}$ In pursuing this objective, the IWL began plotting what Italy's 'Duce' of wine making, Arturo Marescalchi, referred to as a 'division of labour between wine growers and a real wine industry', which would stimulate the industrial scale production of higher quality Italian wines, 'destined for direct consumption' not only abroad but, more critically, among domestic connoisseurs. ${ }^{37}$

Mussolini's appointment as prime minister in October 1922 was, perhaps unsurprisingly, well received among the country's pro-wine campaigners. Having repeatedly, and unsuccessfully, attempted to cultivate a more fruitful relationship with the ill-fated liberal government during the immediate post-war years, the formation of a fascist-led Chamber of Deputies appeared to many prowine lobbyists as a favourable changing of the proverbial winds of political power in Rome (Figure 1). 'The new year begins with an atmosphere of renewed, vigorous faith', Marescalchi exclaimed in the January 1923 issue of Enotria, the UIV's monthly wine themed news and culture magazine, continuing: in addition to the 'memorable spectacle' of the March on Rome and the 'iron clad cooperation given to Italy by the young resolute masses last October', 1922 had witnessed a 'historic harvest' for the peninsula's wine growers. Fascism's 'orderly, but powerful, revolution', he insisted, 'will soon bear its fruits' for the Italian wine making industry, so long as they 'put themselves on the path for collaborating as best as they can' with this 'vital, renewing movement'. By partnering with the fascist government to improve the quality of the peninsula's typical wines (vini tipici), the IWL would bring honour to 'the name, dignity, and greatness' of Italy both domestically and 'beyond the mountains and. . . the seas'. In this way, the country's wine Duce jubilantly concluded, Italian wine making would make its contributions to 'this period of healthy renewal'. ${ }^{38}$

Marescalchi's optimism was not misguided. In March 1924 Mussolini's Chamber of Deputies approved a handful of agro-industrial regulations, which were designed to begin implementing the wine lobby's hoped for 'division of labour' within the country's wine growing industry. ${ }^{39}$ Intended to encourage the production, as well as consumption, of 'genuine wines with special qualities', the 'Provisions for the Protection of Typical Wines' inaugurated a government sponsored programme by which qualified producers could establish typical wine growing consortia 'for the protection of the name of their product'. In addition to mandating a minimum of five producers, prospective consortia were required to adhere to a variety of rigorous cultivation and vinification standards which, above all, included the production of wines which were 'maintained constantly for the same type'

35 Ercole Brambilla, 'L'economia vinicola nazionale e il suo incremento nel dopo guerra', La vita internazionale (Oct. 1919), 434.

36 Many of the objectives and approaches adopted by the IWL during the interwar years had already been pursued and largely achieved by France's industrial wine merchants (négociants) during the late nineteenth century. For an excellent history of wine growing, mass marketing and nationalisation in France, see Guy, When Champagne Became French.

37 A. Uttini, 'Impressioni sulla Settimana Nazionale del Vino', Enotria (May 1923), 469; Marescalchi, Per lo sviluppo della industria enologica italiana, 87. Emphasis is my own.

38 Ibid., 'Restaurazione Nazionale', Enotria (Jan. 1923), 337-8.

39 'Disposizioni per la difesa dei vini tipici'. Although officially passed into law on 7 March 1924, earlier iterations of the vini tipici regulations had been slowly making their way through the Chamber of Deputies since December 1921. See 'La convenzione di Madrid e la difesa delle denominazioni di origini', Enotria (Feb. 1922), 61; 'Per l'unificazione dei metodi analitici sui vini e dei criteri di genuinità', Enotria (July 1922), 142 and 'La difesa del nome dei vini tipici', Enotria (Jan. 1924), 18. 

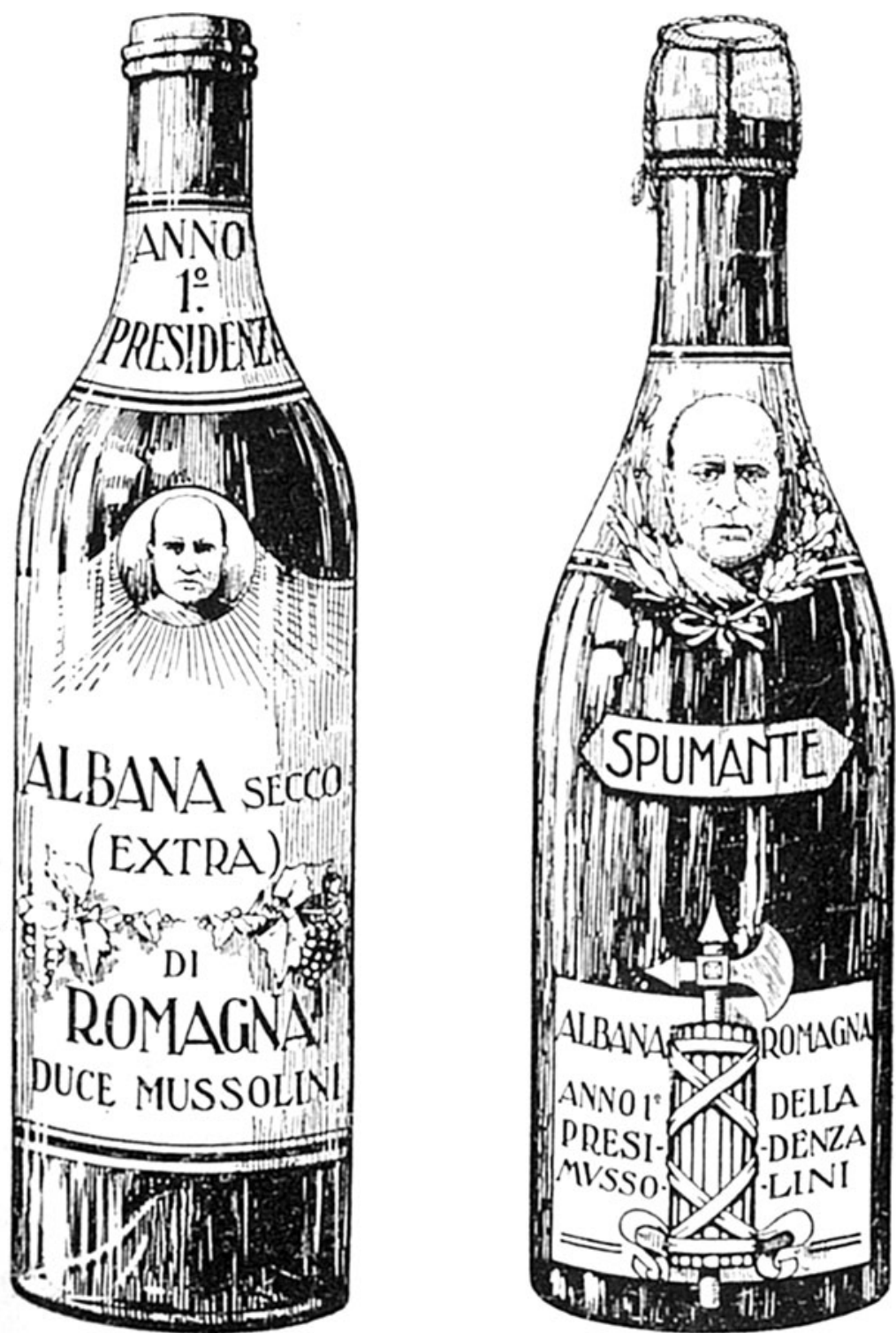

Figure 1. Italy's Industrial Wine Lobbyists Celebrate the Advent of Benito Mussolini's Prime Ministry Enotria (January 1923), 346.

between producers. In order to legally enforce these 'special features', each registered consorzio was obligated to be co-governed by a board of directors, which were to be chosen from among the consortium's largest by volume wine growers and, most importantly, a licensed wine maker (enotecnico), whose job it was to enforce an organoleptic consistency between the consortium's various producers. ${ }^{40}$ In standardising and modernising what IWL spokesmen frequently referred to as Italy's 'wine aristocracy', the fascist government's typical wine growing regulations served as a significant milestone for the country's pro-wine campaigners as they transitioned Italian viti-viniculture between a pre-industrial,

40 See articles $1,2,8$, and 11 in 'Disposizioni per la difesa dei vini tipici'. 
regionally constrained system of largely 'inferior' production and a centralised, and government regulated, inter-regional wine making industry. ${ }^{41}$

\section{Wine, Alcohol and Medical Authority}

In the months leading up to the fascist government's vini tipici regulations the IWL launched a wideranging public relations campaign, which was designed to stimulate the consumption of typical Italian wines among the 'educated classes' by recontextualising vino italiano as a wholesome 'national beverage'. ${ }^{42}$ 'There is a great need to act deeply among the bourgeois masses', exclaimed Marescalchi in The Wine Trade (Il commercio vinicolo), commenting on the wine making industry's culture shaping challenges, 'above all in restoring wine's honour'. ${ }^{43}$ On 28 September 1923 the UIV inaugurated the Committee for the Defence of Italian Wine (Comitato per la difesa del vino italiano; CDVI) at its headquarters in Milan, whose purpose, according to Enotria's editorship, was to 'defend wine ... from the attacks of prohibitionists and anti-vinisti' in Italy, highlight the beverage's 'alimentary and hygienic virtues' and, ultimately, promote a higher consumption of 'good Italian wine' among bourgeois and upper-class connoisseurs. ${ }^{44}$ Since 'the oenological treasures of our country are still little known and appreciated' both within and beyond Italy's borders, the UIV's leadership beseeched the peninsula's luxury wine growers, merchants and industrialists to begin offering 'generous contributions' in support of the CDVI's forthcoming pro-wine propaganda campaigns. ${ }^{45}$

Among the Comitato's preliminary objectives was distinguishing between the country's vini tipici and various other types of alcoholic beverages. Stemming largely from developments during the tumultuous years both before and immediately following the First World War, wine alcoholism (vinismo) had come to be considered as more or less synonymous with popular alcohol dependency among members of Italy's political leadership and, more significantly, many middle-class and wealthy consumers. ${ }^{46}$ In the hopes of significantly improving Italian wine's reputation, the CDVI launched a publicity campaign which underscored the various physiological and social consequences of consuming heavy spirits and, conversely, the advantages of responsible, or moderate, wine consumption.

In pursuing this objective, the Comitato began commissioning pro-wine op-eds by a handful of so-called 'medical celebrities' in some of the country's most widely read newspapers and magazines. ${ }^{47}$ In the April 1923 issue of The Good Counsellor (Il buon consigliere), for instance, Dr. Francesco Sturla highlighted wine's unique hygienic and alimentary qualities. Heavy spirits, when consumed in any quantity, he contended, 'poison ... the human organism', whereas wine, 'when consumed in moderation', served as a valuable source of daily nutrition. ${ }^{48}$ On average, Sturla explained, habitual wine consumers enjoyed a greater physiological resistance to various types of diseases, including malaria and tuberculosis, when compared to habitual consumers of beer or heavy spirits, and were less predisposed to developing long-term degenerative illnesses than those who abstained from consuming Italy's salubrious, 'millennial' beverage. ${ }^{49}$ 'So long live wine', Sturla loudly exclaimed, 'and death to alcohol'. ${ }^{50}$

The following year the CDVI surveyed a random sampling of community physicians from the vineyard-terraced province of Alessandria for their professional judgements regarding 'the value of wine for our people'. 'If serious accusations against wine are to be sustained', Marescalchi reasoned

\footnotetext{
41 'Fervore di preparative per la $1^{\text {a }}$ Mostra mercato Vini Tipici d'Italia', Enotria (July 1933), 462.

42 Notari, L'arte di bere, 113; Marescalchi, Guida Gastronomica d'Italia, 4.

43 Ibid., 'Una buona disposizione', 1.

44 'Il comitato di azione per la difesa del vino', 629; 'La "Casa del Vino”', 68; Marescalchi, 'Comitato Difesa Vino Italiano', Enotria (Aug. 1925), 193.

45 'Per la difesa del vino', Enotria (Feb. 1924), 47.

46 Contro l'alcoolismo (Jan. 1922), 7.

47 Marescalchi, 'La riabilitazione del vino', 1.

48 Francesco Sturla, 'Contro l'alcool ma non vino', Enotria (Jan. 1923), 349.

49 Marescalchi, 'L'opinione pubblica e i problemi vinicoli', Enotria (Apr. 1923), 433.

50 Sturla, 'Contro l'alcool ma non vino', 349.
} 
in the August 1924 issue of Enotria, justifying the inquest's significance, 'they would have to come from these villages' where the paesani had moderately consumed locally produced wines for innumerable generations. 'I have the honour to inform you', replied one physician from Casale Monferrato, 'that I am fully convinced that the moderate use of wine during meals is a coefficient of health and a refreshment for our people'. Another physician, from the nearby commune of Cremolino, added: 'I have never certified cases of cirrhosis of the liver, of severe alcoholism, [or] of alcoholic dementia' which, in any case, 'only occur in large cities due to the use, and abuse, of highly alcoholic beverages'. ${ }^{51}$ Those who regularly consume vino 'as a family and not an osteria beverage', Marescalchi concluded confidently, enjoy immunity from the ravages of alcohol dependency. ${ }^{52}$

Such pleadings for moderation over indulgence, fortunately, were echoed by the head of government himself. During his infamous Ascension Day speech, Mussolini expounded on the epidemic of 'wine abuse' in Italy. In acknowledging the 'phenomenon' of 'alcohol-related mortality', the Duce cautiously signalled his regime's allegiance with the commercial objectives of the country's typical wine growers: 'I hope that, at this point, the organisers of the recent anti-prohibitionist congress' which, of course, had been coordinated by members of the IWL - 'will not fear what I have to say'. While largely a teetotaller himself, Mussolini explained, he was not a supporter of 'complete abstinence', continuing:

I believe that if reasonable amounts of alcohol had really harmed humanity, at this point the human race would have completely. . . disappeared because fermented liquids have been consumed since prehistoric times. ${ }^{53}$

Buoyed by the Duce's approval of their campaign's catchword phrasings and objectives, many wine lobbyists hoped, the moderate consumption of the peninsula's luxury wines would enjoy a greater visibility, as well as acceptance, among Italian consumers.

\section{Combatting 'Foreign' Beverages and Practices}

Beyond highlighting wine's hygienic qualities, the wine lobby produced a wide range of pro-wine marketing materials which were designed to 'combat' what Marescalchi referred to as the 'deplorable snobbery' of the country's middle and upper classes. ${ }^{54}$ Instead of offering their loved ones a 'glass of sweet or dry white wine', or perhaps a 'reassuring sparkling wine', Dr. Alfredo Masoni complained in his monthly opinion column in Enotria, 'The Doctor's Word', members of 'high society' had taken up the 'decadent' fashion of serving 'the tea of British domains' and 'British-branded cookies' during their teatime receptions and soirées. ${ }^{55}$ The distressing popularity of foreign aperitifs among these demographics, too, concerned many of Italy's pro-wine campaigners. 'Among the strangest, and certainly not innocuous, aberrations of fashion', complained Marescalchi, was 'the spread of cocktails' among the country's bourgeois and wealthy households. Emanating from the smoky jazz clubs of New York City, he grumbled, this 'American novelty' had begun to pollute these Italians' 'physiological, artistic and psychological tastes'. Cocktails, in particular, were composed of a potentially hazardous combination of non-Italian substances, he continued, including gin, whisky and brandy, along with various other types of adjunct ingredients. Signalling the Italian wine making industry's forthcoming 'battle' against the 'invasion' of imported commodities, tastes, and habits in Italy, Marescalchi declared: 'Down with the cocktail and the like! ${ }^{56}$

${ }^{51}$ Marescalchi, 'Il valore del Vino per le nostre popolazioni: Inchiesta fra i medici del Piemonte', Enotria (Aug. 1924), 227-9.

52 Ibid., 'Il vero alcoolismo: sintomi da curare', Enotria (Oct. 1921), 344.

53 Mussolini, Discorso dell'Ascensione, 14. Emphasis is my own.

54 Marescalchi, 'Prodotto nazionale', Il commercio vinicolo (19 Dec. 1931), 1.

55 Alfredo Masoni, 'La parola del Medico: Il vino in società', Enotria (Sept. 1934), 585.

56 Marescalchi, 'Cocktail, vermut e vino', Enotria (Sept. 1937), 357-62; Ibid., 'Aprire gli occhi', Il commercio vinicolo (5 Sept. 1931), 1. Emphasis is my own. 


\section{Basta porcherie...}

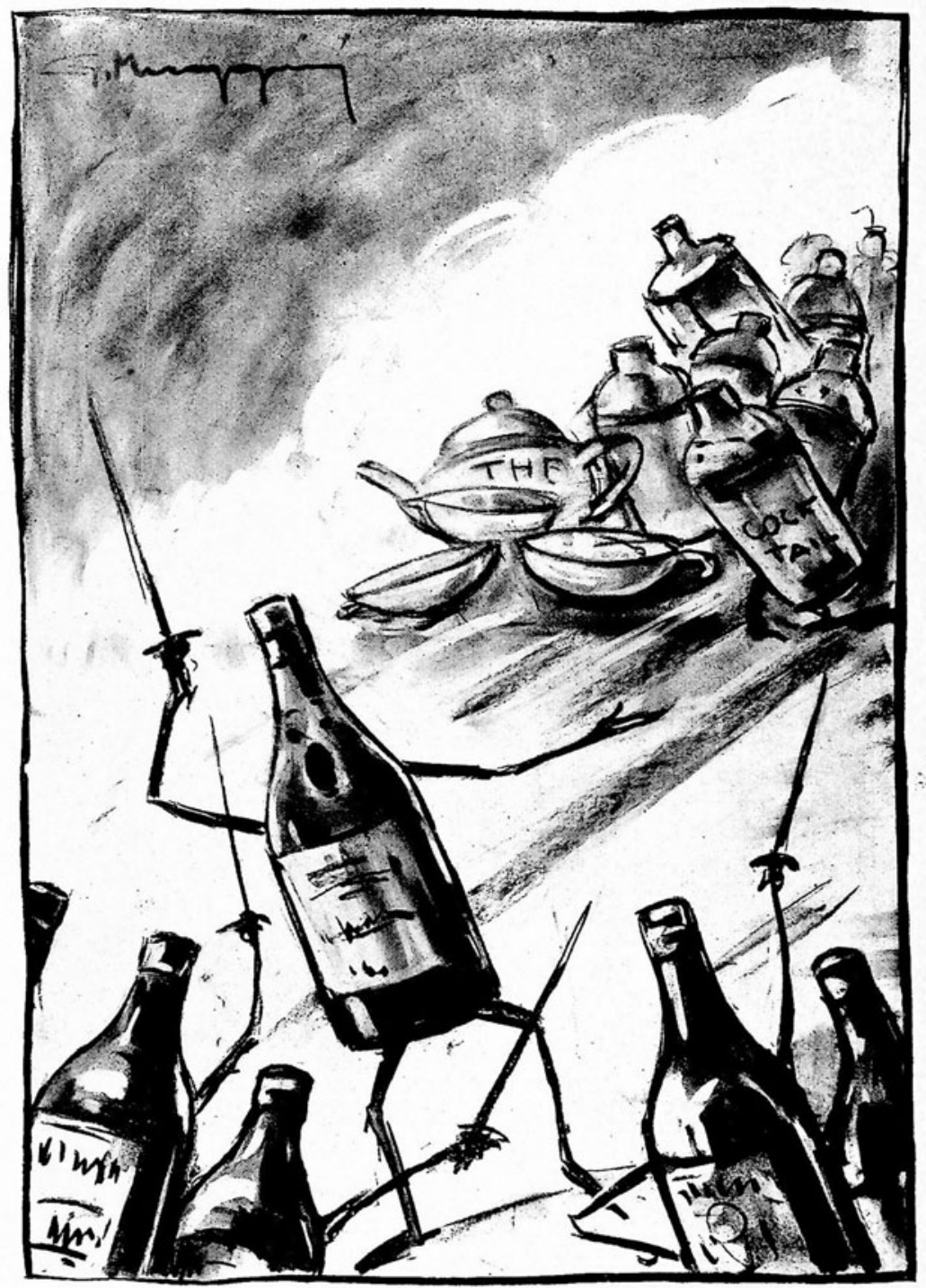

Largo ai vini d'Italia sulle mense d'Italia!

Figure 2. The 'Battle' between Indigenous and Foreign Consumerisms Enotria (April 1934), 245.

A cartoon published in the April 1934 issue of Enotria fully captured the IWL's 'wine battle' in regard to the unwelcomed infiltration of 'exotic' beverages. ${ }^{57}$ In this humorous fumetto, a squad of anthropomorphised Italian wine bottles are seen preparing for a squabble with pots of tea, cocktail shakers and other, mostly foreign, beverages and utensils (Figure 2). Drawing loosely upon the ideologically charged imagery of Mussolini's squadristi who, during the so-called Red Biennium (1919-

57 “'L'Ora della merenda”, 1; 'Riunioni vinicole e propaganda', 1; G.M., 'L'arte del bere', 57. 
20), 'exorcised' the Italian peninsula of the international 'Bolshevik menace', Enotria's pro-wine cartoon harshly distinguished between indigenous and foreign consumerisms and, by implication, characterised the IWL in partnership with the fascist dictatorship as, in Marescalchi's words, 'the supreme guardian of the health and progress of [the Italian] people'. 58 'Enough with the rubbish', the fumetto's caption proclaimed, 'Italian wines: Off to the dining tables of Italy!'

To combat such 'snobbish' or unpatriotic fashions among these demographics, the pro-wine lobby launched a wide-ranging public relations campaign which aimed at providing bourgeois housewives with what Marescalchi coined as a 'wine education'. ${ }^{60}$ In doing so, the IWL hoped to reform the 'female palate' in favour of the peninsula's typical wines, indirectly influence the consumer tastes and habits of their families and friends and, ultimately, recontextualise the responsible appreciation of the country's typical wines as a wholesome and quintessentially Italian practice. ${ }^{61}$

As spouses, mothers and homemakers, wine lobbyists were wholly aware, middle-class and privileged Italian women played a remarkably influential role in the shaping of their husbands' and children's consumer preferences. In preparing their family's meals, Emanuela Scarpellini has rightly pointed out, women were 'expected to be as thrifty as possible, avoid wastage' and, above all, 'to find Italian substitutes for everything' ${ }^{62}$ Indeed, throughout the fascist ventennio the regime frequently exhorted Italian women to always consider the 'national interest' when making weekly purchases for their households. Those who have 'good taste and a sense of national duty', Bianca Flury Nencini forcefully proclaimed in the March 1935 issue of The Fascist Woman (La donna fascista), highlighting one of the dictatorship's primary stratagems for mobilising Italian women in support of its 'Buy Italian Products' campaign, 'will demonstrate to snobbish women that, next to a foreign product, there is always an Italian equivalent'. ${ }^{63}$

To instil a 'wine consciousness' among Italian housewives, the IWL began publishing a variety of how-to guides on the fundamentals of l'arte di bere in some of interwar Italy's most widely circulated women's periodicals and magazines. ${ }^{64}$ In the April 1934 issue of The Woman (La donna), for instance, Luigi Garrone provided his readers with a variety of helpful tips and recommendations for 'Italian-style drinking' (bere allitaliana) (Figure 3). Following a handful of detailed organoleptic descriptions of various Italian wines, along with their French, German and Hungarian equivalents, Garrone illuminated the finely tuned 'art' of skilfully pairing and presenting Italian wines with specific dishes. 'Wines ... must be served in fine glassware', he explained, whose capacity ought to decrease in accordance with the beverage's strength. For vini rossi, especially those of 'an exceptional fragrance', Garrone recommended 'a temperature ranging from eighteen to twenty-two degrees'. White wines, on the other hand, ought to be 'served fresh, at a temperature of four or six degrees'. Any successful lunch or dinner 'is not just a jumble of food and wine', he counselled, subtly interweaving women's proficiency with bere allitaliana with bourgeois propriety, but rather 'a well-organised sequence of sensations', beginning with 'muted tones' and gradually increasing in intensity 'until it reaches a pitch' of harmonious flavours, aromas and textures. Any respectable Italian woman, Garrone subliminally concluded, ought to be familiar with wine's irreplaceable contributions to this complex gastronomic 'symphony. 65

58 Marescalchi, 'L'educazione vinicola', 1.

59 Enotria (Apr. 1934), 245.

60 Marescalchi, 'L'educazione vinicola', 1.

61 Notari, L'arte di bere, 77.

62 Scarpellini, Material Nation, 88; Victoria De Grazia, How Fascism Ruled Women: Italy, 1922-1945 (Berkeley: University of California Press, 1993), 41-115; Paul Ginsborg, Family Politics: Domestic Life, Devastation and Survival, 1900-1950 (New Haven: Yale University Press, 2014), 139-225.

63 Bianca Flury Nencini, 'La valorizzazione del prodotto italiano', La donna fascista (5 Mar. 1935), 3; Adam Arvidsson, Marketing Modernity: Italian Advertising from Fascism to Postmodernity (New York: Routledge, 2003), 22-43.

64 Marescalchi, 'L'opinione pubblica e i problemi vinicoli', 433.

65 Luigi Garrone, 'Bere all'italiana: Come si deve bere', Enotria (June 1934), 380. Although originally published in the April 1934 issue of The Woman (La donna), Garrone's recommendations for 'Italian-style drinking' were happily republished by the UIV in the June 1934 issue of Enotria. 


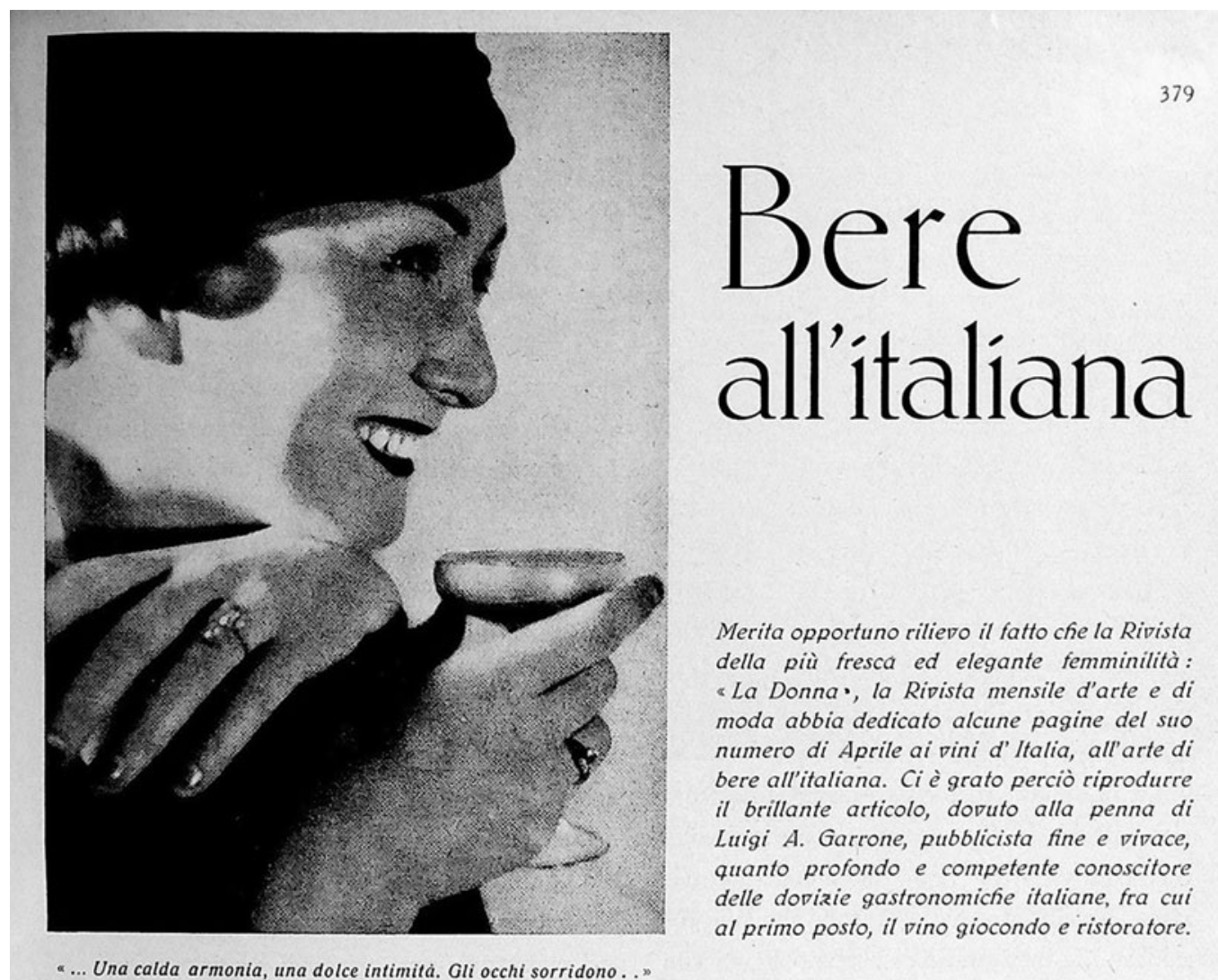

Figure 3. Teaching Bourgeois Italian Women the 'Art' of 'Italian-Style Drinking' Luigi Garrone, 'Bere all'italiana: Come si deve bere,' Enotria (June 1934), 379.

Wine lobbyists' campaign for promoting the 'art of drinking' among Italian housewives, however, was not limited just to women's magazines. In June 1934, for instance, Enotria announced the formation of an Italian Women's Propaganda Committee for Family Oriented Wine Consumption (Comitato femminile italiano di propaganda per il consumo del vino nelle famiglie; CFIPCVF), which was designed to stimulate the substitution of 'exotic concoctions with our exquisite wines, in every occasion of family life' and 'in friendly and worldly gatherings' ${ }^{66}$ Led by a delegation of women from Italy's prosperous north, the CFIPCVF intended to deploy a variety of newspaper articles, conferences, radio programmes, films and other materials and platforms in support of the organisation's objectives. ${ }^{67}$

The following year the members of the Comitato femminile coordinated an Italian wine themed reception at the Grand Hotel Gardone Riviera on the shores of Lake Garda. Held on 26 May 1935, and attended by over 1,000 people 'belonging to the most distinguished families of Upper Italy', the gathering's coordinators hoped to convince its esteemed guests of 'the superiority of Italian wines not only to foreign wines, but also to other beverages'. ${ }^{68}$ Surrounded by elegantly decorated

\footnotetext{
66 'Riunioni vinicole e propaganda', 1.

67 'Assemblea dei Consorzi per la viticoltura', L'assistenza sociale agricola (Mar.-Apr. 1936), 109; 'Comitati femminili di propaganda al vino', Enotria (June 1934), 398. The Women's Propaganda Committee for Family-Oriented Wine Consumption was reportedly inspired by a pro-wine women's organization in France. See 'La signora Pollet Combrouze', Il commercio vinicolo (21 Apr. 1934), 1 and 'Il Comitato femminile per il consumo del vino', Il commercio vinicolo (12 May 1934), 1.

68 “'L’Ora della merenda"', 1.
} 
table tops adorned with flowers, tasty appetisers and 'the most varied and delicious Italian wines', the reception's numerous speakers, which included Marescalchi himself, repeatedly implored attendees to 'banish the exotic, monotonous tea from their living rooms' and, in its place, dedicate their afternoon 'snack time' to the consumption of the peninsula's 'exquisite typical national wines'. ${ }^{69}$ Intending to reinforce the exclusive gathering's primary marketing objective, the CFIPCVF composed a special jingle: 'From Gardone begins the motto: "Always wine in the parlour!" ('Da Gardone parta il motto: "Sempre vino nel salotto!"') 70

\section{Towards the 'Rebirth of the Wine Tavern'}

In addition to concentrating on the salons and dining tables of Italy's middle-class and wealthy households, pro-wine campaigners also hoped to rehabilitate wine's presence, as well as connotations, within the country's various public spaces of bourgeois consumption. Beginning in the late 1920s the IWL began working towards 'the rebirth of the wine tavern'. ${ }^{71}$ For the peninsula's vini tipici, wrote Marescalchi in The Wine Trade, 'the rehabilitation of the taverns is of the utmost importance'. ${ }^{72}$ According to many wine lobbyists, there was 'no more room for the old ... taverns', which were purportedly 'absent of every good taste' for 'an intellectual audience which senses the new times'. ${ }^{73}$ In contrast to the gloomy, smoky and morally questionable atmosphere of the country's popular osterie and bettole, fascist Italy's 'new tavern' would feature clean, bright open spaces, be filled with 'tasteful' furniture and stimulating decorations and, ideally, be frequented by a 'respectable', well-behaved clientele. Designed according to 'the principles of modern construction', wrote one outspoken pro-wine campaigner, Werther Bellodi, the 'reformed' osteria would feature 'lots of daylight streaming in from the [building's] wide windows', various 'Bacchic friezes along the walls' and, highlighting the IWL's longstanding campaign for rebranding Italian wines as 'family-friendly' beverages, would serve as a common space for 'all sexes'. Such an idea, Bellodi concluded hopefully, would naturally produce 'followers willing to implement it, simplify it and even improve upon it substantially. ${ }^{74}$

By mid-decade, a scattering of 'rehabilitated' wine taverns had been established in some of the peninsula's most densely populated cities, including Florence, Brescia and Trieste. 'The rebirth of the beautiful osteria in many cities', exclaimed Guido Marangoni in a glowing review of one of Brescia's then recently opened 'new taverns', 'has come to redeem the temple of [Italy's] popular beverage from the poor reputation which surrounded it during a not-so-distant epoch'. Designed by Ettore Sottsass, Sr., and embellished with 'pictorial decorations. . . inspired by a delightful, moderate and polite folklore' by Alberto Stolz and Giuseppe Mozzoni, the Osteria dell'Aria Valtriumplina reportedly promised Brescia's 'petitbourgeois' masses an atmosphere of 'cordial intimacy'. Their children could 'play in complete freedom and in a cool garden environment', Marangoni happily suggested, while they enjoyed a leisurely game of bocce, along with 'good wine and excellent food' (Figure 4). ${ }^{75}$

\footnotetext{
69 In 1931 The Italian Woman (La donna italiana) - one of fascist Italy's most widely read women's magazines - published a glowing biographical profile of Marescalchi who was then serving as Italy's Undersecretary for the Ministry of Agriculture and Forestry. See 'Uomini e donne della nostra epoca: S. E. Arturo Marescalchi, Sottosegretario all'Agricoltura', La donna italiana (July-Aug. 1931), 435-6.

70 “"L'Ora della merenda", 1; 'Un dovere nazionale: Trasformare l'“ora del tè" in "ora del vino e dei biscotti," La voce del consumatore (15 July 1932), 14. In spite of wine lobbyists' numerous campaigns for 'combatting' the popularity of 'exotic' beverages among the middle and upper classes, many women's magazines frequently published articles, short stories and advertisements which promoted, in one way or another, these decidedly 'un-Italian' tastes and habits. See 'Pranzi Bridge', La donna (Mar. 1933), 45; Elena Morozzo della Rocca, 'Eleganza della tavola', La donna italiana (June 1933), 353; 'Per la sete d'estate', La donna (Aug. 1933), 38-9; and Maria Magri Zopegni, 'Ecco l'amore: novella', La donna italiana (May 1936), 203.

71 RUSTICO, 'La rinascita dell'osteria', 3.

72 Marescalchi, 'La riabilitazione delle osterie', 1.

73 Ibid., 'I locali di mescita del vino', L'alimentazione italiana (15 Dec. 1938), 3.

74 Werther Bellodi, 'L'osteria ideale', Enotria (Aug. 1933), 534-6.

75 Marangoni, 'L’osteria nel mondo', 428-35; RUSTICO, 'La rinascita dell'osteria', 3.
} 


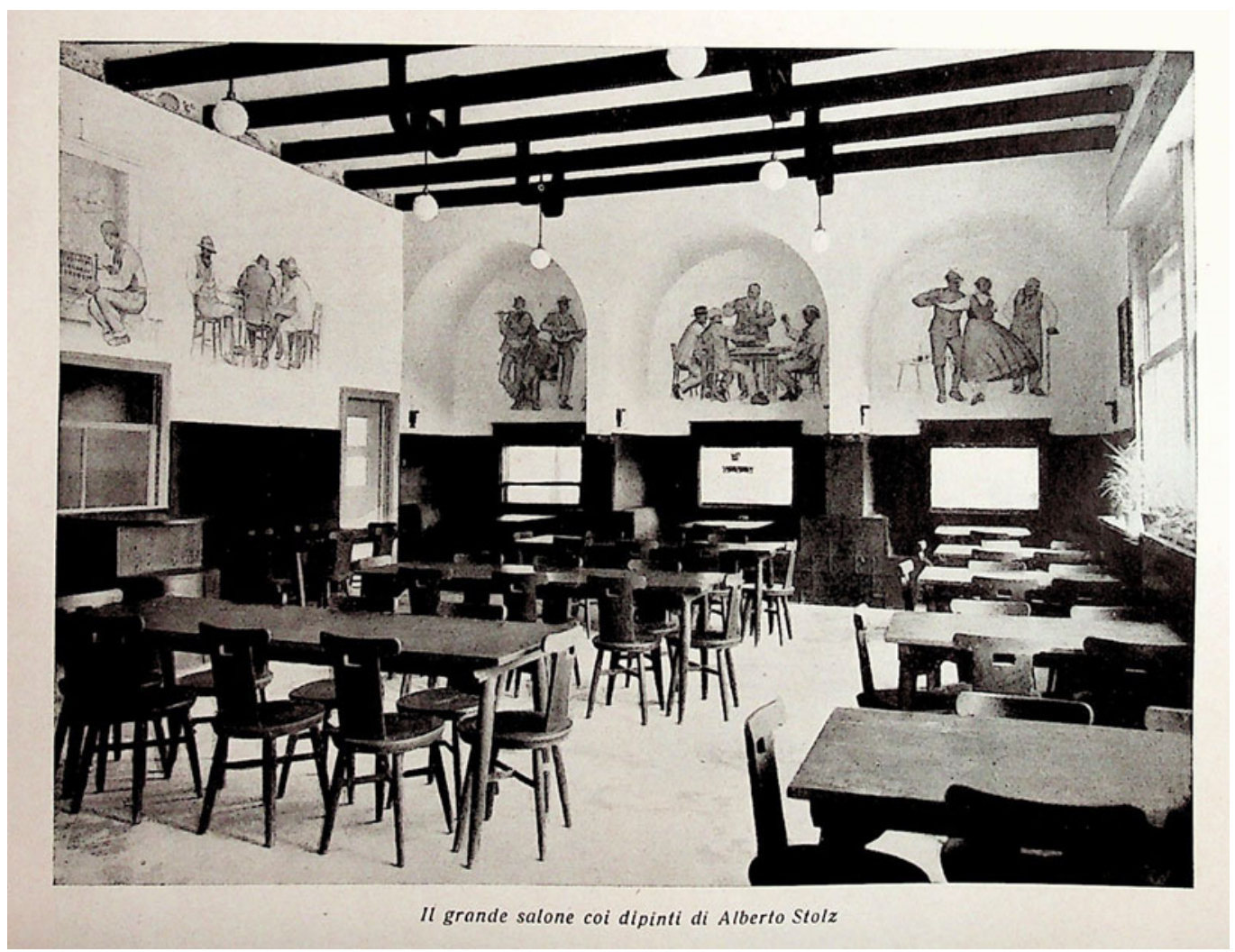

Figure 4. The Great Hall in Brescia's Osteria dell'Aria Valtriumplina Enotria (June 1933), 431.

The IWL-sponsored 'reformed' osterie, however, were largely constrained in the degree to which they were capable of broadening consumers' oenological palates. Similar to the popular osterie and bettole before them, the country's 'new taverns' catered largely to regionally produced typical wines, which merely reinforced the very parochial consciousness the IWL, as well as the Duce's dictatorship, was hoping to suppress. In order to encourage the materialisation of a truly national wine market in Italy, many wine lobbyists frequently contended, the Italian wine growing industry would have to develop a centralised, inter-regional network of shops at which Italians could sample the full spectrum of the peninsula's oenological patrimony, receive professional recommendations on selection, storage and pairing from knowledgeable personnel and, if so inclined, purchase a bottiglia or a fiasco to take home with them.

Beginning in 1933 pro-wine campaigners began opening up a handful of hybrid osteria-shops which provided Italian consumers with 'an assortment of more than two hundred typical Italian wines' in a 'characteristically family environment'. ${ }^{76}$ Conceived and designed by Marescalchi and Giovanni Dalmasso - the Director of the Royal Experimental Viticulture and Oenology Station in Conegliano - the IWL's 'wine shops' (botteghe del vino) featured a comprehensive collection of luxury wines for consumers to choose from. The colourful displays of wines, explained Marescalchi in Italian Nutrition (L'alimentazione italiana), should be 'accompanied not only by the indication of the price but also by the wine's synthetic description' with respect to its 'origin, history (if any)', as well as any other recommendations for storage, presentation and pairings. ${ }^{77}$

\footnotetext{
76 'La "Bottega del Vino" di Trento', Enotria (Aug. 1937), 350.

77 Marescalchi, 'I locali di mescita del vino', 3.
} 
While limited to just a handful of, mostly northern, metropolises, the botteghe system nonetheless played a pivotal role in the wine lobby's campaign for spreading an awareness of and a deeper appreciation for the peninsula's typical wines among bourgeois connoisseurs. ${ }^{78}$ Between June 1936 and April of the following year, for instance, Trieste's wine shop reportedly sold some 40 hectolitres of 'wine of various qualities' by the glass, 42,000 bottles and 12,000 flasks to nearly 68,000 visitors, bringing in a gross revenue of 540,000 lire. Among the nearly 150 vini tipici offered, Enotria reported, the most frequently requested were Traminer, Soave, Valpolicella and various types of moscati and passiti wines, which highlighted 'the remarkable participation of the female element' at the city's wine shop. ${ }^{79}$ Proclaiming that the 'Bottega del Vino has won over the bettola' in its September 1933 issue, Enotria's editorship confidently predicted that Italy's 'rehabilitated' taverns and botteghe would lead to 'a huge consumption of wine' during the subsequent years by 'creating a satisfying environment for the good taste of educated people'. 80

\section{Gastronomy, Heritage and Mobility}

In the early 1930s the fascist regime began mobilising Italians via a wide range of 'interprovincial' domestic tourism initiatives, which were intended to strengthen the national economy and, as D. Medina Lasansky has aptly contended, stimulate a 'shared sense of national patrimony that erased provincial difference'. ${ }^{81}$ Supported by regime sponsored publications such as The Streets of Italy (Le vie d'Italia) and The Hotel in Italy (L'albergo in Italia), as well as the popular trains (treni popolari) programme, the dictatorship's domestic tourism campaigns helped recontextualise 'the practice of visiting Italian historic sites' as quintessentially Italian. ${ }^{82}$

In response to the growing numbers of paesani traveling to or from one of Italy's newly minted 'national heritage' sites, the IWL partnered with the dictatorship in promoting what Marescalchi and others referred to as 'gastronomic tourism'. 83 'We believe that Italians . . . would benefit from seeing very interesting places' featuring 'natural beauties, historical memories' and 'manifestations of [regional] customs', boasted one wine lobbyist in Enotria which, above all, included 'oenological itineraries' to the peninsula's typical wine growing provinces where, it was hoped, Italian sightseers could savour the country's 'exquisite wines . . . on the spot' ${ }^{84}$ Published in 1931 by the Italian Touring Club, the Gastronomic Guide of Italy (Guida gastronomica d'Italia) encouraged the 'educated classes' to 'visit their country' by happily nibbling and sipping their way through the peninsula's bucolic backroads, vineyards and villages. ${ }^{85}$ 'With this Guide in Italian hands', Marescalchi expounds in the volume's Preface, holidaymakers could 'get to know our country better' through the 'joy of acquainting themselves with the delightful tastes, myths and . . . delicacies' of Italy's various regional gastronomies and accompanying folkways. Organised according to each of Italy's twenty regions, with an additional chapter dedicated just to the city of Rome, the Guida provided meticulous descriptions of, as well as the 'remote traditions' behind, the country's 'classic meals' and standardised wines. Having been curated by the 'apostle' of Italian wine making himself, however, the Guide concealed yet a deeper motivation than just the promotion of gastro-tourism. ${ }^{86}$ 'This guide highlights another

\footnotetext{
78 Ibid., 'Bottega del vino', Il commercio vinicolo (31 Mar. 1934), 1; Marangoni, 'La "Bottega del Vino” di Trieste e l'evoluzione enologica della donna', Il commercio vinicolo (30 Oct. 1937), 1; 'Una “Bottega del Vino” a Conegliano', Enotria (Jan. 1937), 41; 'La “Bottega del Vino” di Trento', Enotria (July 1937), 350; Giovanni Dalmasso, 'Botteghe del vino', Enotria (June 1940), 170-6.

79 'Alcune cifre della "Bottega del Vino" di Trieste', Enotria (Aug. 1937), 350.

80 'Una Bottega del Vino nella III "Settimana Faentina”, Enotria (Sept. 1933), 569.

81 D. Medina Lasansky, The Renaissance Perfected: Architecture, Spectacle, and Tourism in Fascist Italy (University Park: Pennsylvania State University Press, 2004), xxxix.

82 'Una visione totalitaria del problema turistico al Convegno Regionale della Federazione Turistica Toscana', L'Albergo in Italia (Jan. 1933), 3; Lasansky, The Renaissance Perfected, 17.

83 'Una visione totalitaria del problema turistico al Convegno Regionale della Federazione Turistica Toscana', 3.

84 'Itinerari enologici', 663.

85 Notari, L'arte di bere, 113; Lasansky, The Renaissance Perfected, 208.

86 'A S. E. Marescalchi', Il commercio vinicolo (26 July 1930), 3. Emphasis is my own.
} 
aspect of our people', Marescalchi explained: that is, 'what they eat and how they drink'. One says "'how one drinks" and not "what one drinks", he continued, 'because the Italian, everyone knows, only drinks wine'. As such, Marescalchi insisted, signalling the type of inter-regional consciousness he and other regime officials were hoping to instil within the minds of Italy's wayward middle and wealthy classes, 'no force of exaggerated publicity' can dissuade the Italian from 'his millennial national beverage'. 87

In addition to food and wine themed sojourns, the IWL aggressively promoted Italy's vini tipici in the cafés and kiosks of the country's largest railway stations. 'One cannot, and must not, forget that the railway restauranteur is an element of hospitality and propaganda of the highest order', Marescalchi explained to his colleagues in The Wine Trade, which is why it must be made clear to them that 'the worthy presentation and offering of [Italian] wines' is a 'national duty. ${ }^{88}$ Between 1929 and 1935 the National Fascist Wine Trade Federation (Federazione Nazionale Fascista del Commercio Enologico; FNFCE), in partnership with the regime's state-owned railway and popular tourism agencies, coordinated a series of peninsula-wide competitions among café concessionaires and restauranteurs for the most original, colourful display of typical wines. Hosted by some 206 participants at virtually all of Italy's major railway stations between South Tyrol and Sicily in its inaugural year alone, the participants of the National Competition between Railway Station Café Concessionaires (Concorso Nazionale fra i Concessionari di Caffe Ristoratori di Stazione; CNCCRS) lured passers-by with spectacular arrangements of wine bottles and flasks - including, in some cases, oversized Chianti fiaschi and fasci littorali - and, in the interest of stimulating sales, affordably priced 'half bottles and half flasks' of various luxury Italian wines. ${ }^{89}$

Beyond the competition's colourful displays, the CNCCRS' coordinators attempted to stimulate 'the most widespread knowledge of our regional wines' by distributing a handful of booklets and brochures on Italy's vini tipici. ${ }^{90}$ In support of the inaugural Concorso Nazionale in 1928, for instance, the FNFCE published 15,000 copies of an illustrated catalogue which included a comprehensive, alphabetically ordered list of 'the best Italian wines'. Titled The Smile Wines of Italy (I vini sorriso d'Italia), the colourful pamphlet was forwarded to the participating cafés and restaurants by the state-owned railway company, who were instructed to generously distribute them among any interested turisti who passed by their spectacular displays. ${ }^{91}$ The following year, moreover, the Federazione Nazionale disseminated an additional 'twenty thousand placards and twenty thousand illustrated brochures on Italian wines' in support of the competition's commercial objectives. ${ }^{92}$

Among Italy's treni popolari sightseers, one of the most popular destinations was Tuscany. In addition to enjoying an afternoon in Florence, many Italian holidaymakers happily attended one of Siena's two biannual Palio horse races, which had only recently been 'resurrected' by Mussolini's regime. ${ }^{93}$

87 Marescalchi, Guida Gastronomica d'Italia, 4. The Guide was complimented by a handful of similar publications during the mid to late 1930s which, much like the former, sought to mobilise Italy's middle and upper classes via interprovincial gastronomic sojourns. Published in 1935, for instance, Paolo Monelli and Giuseppe Novello's The Wandering Glutton (Il ghiottone errante) hoped to 'remind Italians of their traditional cuisines' by chronicling their 'gastronomic and wine journey through Italy'. See Monelli, Il ghiottone errante: Viaggio gastronomico attraverso l'Italia (Milano: S. A. Fratelli Treves Editori, 1935).

88 Marescalchi, 'Ristoratori ferroviari', 1.

89 'Primo Concorso Nazionale per l'offerta dei vini tipici regionali nei caffè ristoratori di stazione', Il commercio vinicolo (2 Mar. 1929), 2; 'I Vini Sorriso d'Italia', Giornale vinicolo italiano (16 Sept. 1928), 456.

90 'Caffè e ristoratori premiati al III Concorso Nazionale per l'offerta dei vini tipici regionali', L'Albergo d'Italia (Mar. 1935), vi.

91 'I Vini Sorriso d'Italia', 456; 'Geniale offerta di propaganda', Il commercio vinicolo (16 Nov. 1929), 3. The FNFCE also published 10,000 copies of The Smile Wines of Italy in German and 50,000 copies in English, which appeared as Italian Wines in 1933. See 'Per la propaganda dei vini italiani nel Nord America', Enotria (Mar. 1933), 197.

92 'Una riunione della Commissione per il II Concorso fra Ristoratori di Stazione per i vini tipici regionali', Il commercio vinicolo (19 Oct. 1929), 3.

93 Stefano Cavazza, Piccole patrie: Feste popolari tra regione e nazione durante il fascismo (Bologna: Il Mulino, 1997), 171244; Lasansky, The Renaissance Perfected, 70. 
Held in both July and August in the city's Piazza del Campo, the Palio di Siena, Lasansky has shown, was intended as both 'educational and entertaining' which, in the hands of regime officials, rendered the 'historical' horse races as 'valuable tools of mass persuasion'. ${ }^{44}$ The Palio, however, was not the only popular activity drawing spectators to Tuscany during the 1930s. In conjunction with the city's 'traditional' horse races, Italy's pro-wine lobby coordinated a large-scale sampling exhibition which was intended to familiarise Italians with their country's conjoined historical, folkloric and oenological heritages.

In August 1933 Marescalchi, together with various other officials affiliated with the regime's Ministry of Agriculture and Forestry, launched the inaugural Exhibition Market of Typical Italian Wines (Mostra-Mercato dei vini tipici d'Italia) at Siena's 'ancient and glorious Medici fortress'. ${ }^{95}$ 'Famous throughout the world. . . for its classic "Chianti", Enotria informed its readership in July, Siena had been 'rightly chosen by the DUCE as the site of the inaugural Mostra-Mercato', which constituted the first comprehensive 'gathering of [Italy's] wine aristocracy'. ${ }^{96}$ Described by its coordinators as an 'intensive marketing system', the vini tipici exhibition sought to encourage an 'evolution of taste' towards the country's standardised wines by, in the words of Mussolini's Agriculture and Forestry Minister, Giacomo Acerbo, 'intensify[ing] the relationships between producers and consumers' in Italy. ${ }^{97}$

In support of both the bi-annual Palio races and the Exhibition Market, the dictatorship approved significantly discounted railway fares to Siena between 3 and 18 August. ${ }^{98}$ As a result of these concessions, the 1933 Exhibition Market was attended by an impressive 143,800 domestic and foreign connoisseurs who, according to one prefectural report, consumed 350,364 glasses of typical Italian wines. ${ }^{99}$ Bringing in 600,000 lire for all of the 513 exhibitors, the Mostra-Mercato's successes, Enotria's editorship proudly announced in October, reportedly influenced the Duce's subsequent decision to establish the vini tipici exhibition as a biennial 'national event'. ${ }^{100}$ By the end of the decade, the Exhibition Market had expanded to include 187 typical wines by 849 producers from as many as seventy-five provinces and with an impressive 225,000 gustatori in attendance. ${ }^{101}$

Organised according to each of the country's principal wine growing provinces, the Mostra-Mercato complex was composed of some forty 'regional pavilions' of 'evocative and symbolic form' in which attendees could sample Italy's typical wines from participating wine growers. ${ }^{102}$ In this way they could familiarise themselves with the lavishly displayed wines, 'personally realising the different qualities that each one has', studying each vino tipico's legally safeguarded zone of production and unique organoleptic properties, and, if so inclined, purchasing a fiasco or bottiglia (Figure 5). ${ }^{103}$

Siena's vini tipici exhibition, however, offered much more than just samples of standardised Italian wines. Indeed, embedded within layout of the Exhibition Market lay an oenological, as well as supra-regional, image of Italy in microcosm. Designed in the Novecento style by Virgilio Marchi in order to, as Enotria explained it, establish 'a varied and picturesque whole' while, simultaneously,

\footnotetext{
94 Ibid., The Renaissance Perfected, 66.

95 'La mostra dei vini tipici a Siena: Aspetti e realizzazione d'una manifestazione perfetta', L'alimentazione italiana (31 July 1935), 2.

96 'Fervore di preparative per la $1^{\text {a }}$ Mostra mercato Vini Tipici d'Italia', 462.

97 'La mostra dei vini tipici a Siena', L'alimentazione italiana (15 Aug. 1935), 2; 'Discorso di S. E. Acerbo in occasione della inaugurazione 1. ${ }^{a}$ Mostra Mercato Vini Tipici d'Italia', in Mostra-Mercato Vini Tipici d'Italia: Catalogo Generale (Siena: S. A. Poligrafica Meini, 1933), xi.

98 'Riduzioni ferroviarie in occasione della prima Mostra-Mercato dei Vini Tipici d'Italia' (14 Apr. 1933), Archivio Centrale dello Stato (ACS), Presidenza del Consiglio dei Ministri (PCM) (1934-1936), 14.1.3621/1.

99 Prefect of Siena to Head of Government (19 Aug. 1933), ACS, PCM (1934-1936), 14.1.3621/1.

100 'Il successo della Mostra di Siena', Enotria (Oct. 1933), 702; Cristiano Focarile, 'La Mostra Nazionale dei vini tipici a Siena: La partecipazione delle Cantine Sociali', La voce del consumatore (Sept. 1933), 13.

101 'I soddisfacenti risultati della III Mostra Mercato dei vini tipici a Siena', L'alimentazione italiana (15-31 Aug. 1937), 6; 'Il lieto successo della IV Mostra-Mercato dei vini pregiati d'Italia a Siena', Enotria (Sept. 1939), 395.

102 Focarile, 'La Mostra Nazionale dei vini tipici a Siena', 13.

103 'Fervore di preparative per la $1^{\mathrm{a}}$ Mostra mercato Vini Tipici d'Italia', 463.
} 


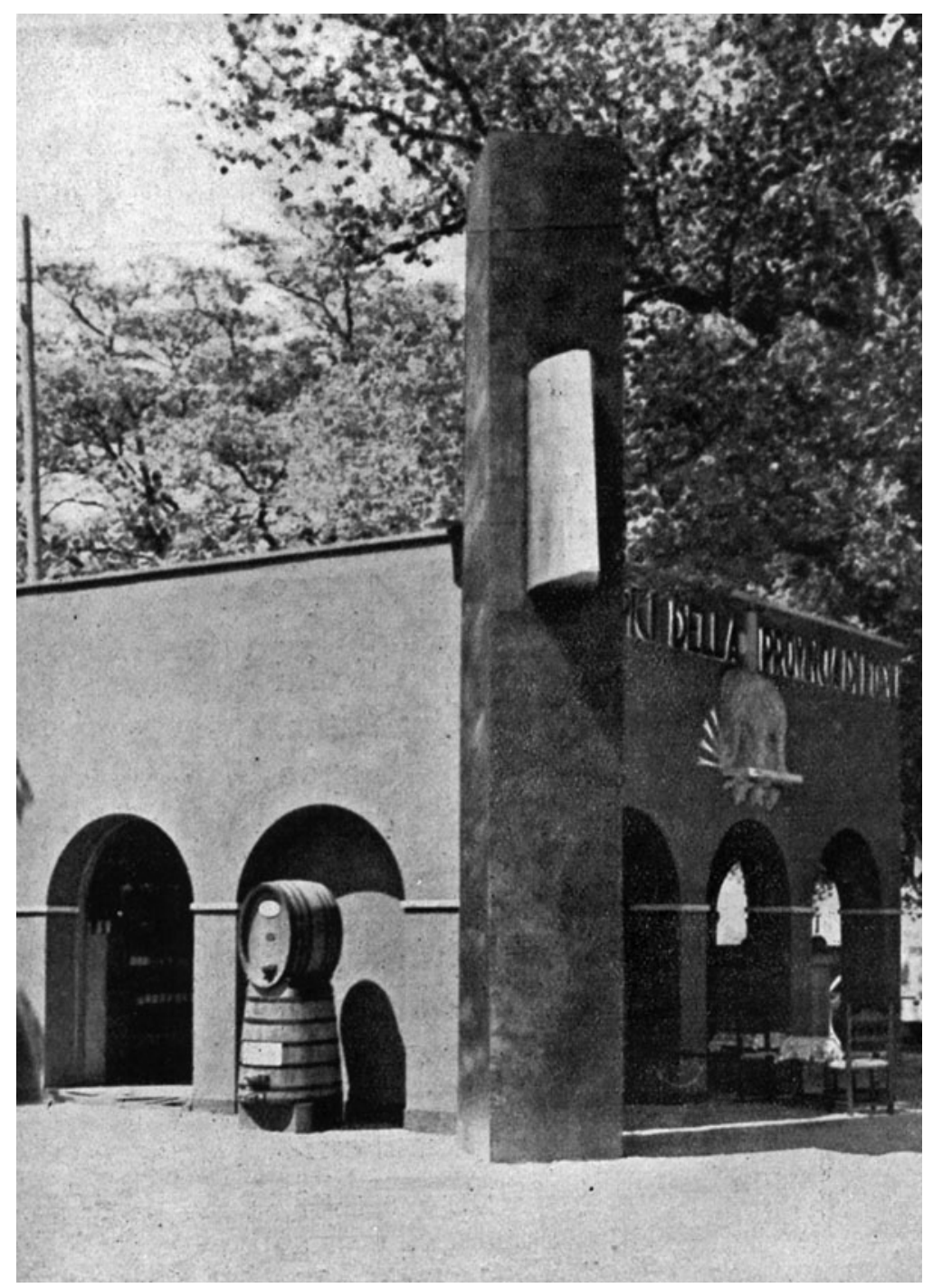

Figure 5. An Oversized fascio littorio on the Exterior of Forli's Wine Pavilion at Siena's 1933 Exhibition Market of Typical Italian Wines

I risultati della $1^{a}$ mostra mercato vini tipici d'Italia - 3-18 agosto 1933-XI (Siena: Consiglio Provinciale dell'Economia Corporative di Siena, 1933), 77.

guaranteeing a 'typical folk variety' among each of the pavilions, the Mostra-Mercato simulated a unified vision of Italian society and culture purportedly via Italians' common heritage of vitiviniculture. ${ }^{104}$ To accomplish this 'exaltation of. . . Italian folklore', each wine growing consortium was responsible for highlighting the 'characteristic[s] of the zone in which' their wines were 'produced' via their padiglione's internal and external embellishments. ${ }^{105}$ 'The presentation of typical wines cannot, and should not, be reduced to a dry and cold presentation of samples, or a collection of more or less dusty bottles', Enotria explained to its readership in 1935 but, rather, must feature 'a vigorous

\footnotetext{
104 Ibid.

105 'La mostra dei vini tipici a Siena', 2; 'Fervore di preparative per la $1^{\text {a }}$ Mostra mercato Vini Tipici d'Italia', 463; 'Concorso per la Mostra dei vini tipici bandito dal Sottosegretariato alla stampa', Enotria (June 1935), 334.
} 
expression' of each province's physical and folkloric settings. ${ }^{106}$ The Emilia-Romagna pavilion, for instance, reproduced 'a picturesque Emilian osteria', complete with rustic tables and benches. 'Every detail' has been 'attended to', Marescalchi happily proclaimed, 'so as to give the visitor a full impression of the Emilia-Romagna's surroundings' ${ }^{107}$ To heighten attendees' immersion experiences, the Exhibition Market's coordinators required the participating vini tipici consortia to employ a handful of 'graceful girls' dressed up in 'rich regional costumes', as The Voice of the Consumer (La voce del consumatore) explained in 1933, which helped strengthen the exhibition's manufactured authenticity of Italy's intertwined folkloric and oenological heritages (Figure 6). ${ }^{108}$ In spatially aggregating the peninsula's typical wines and displaying them alongside their accompanying regional 'environments', the Mostra-Mercato encouraged Italians to imagine their country as a composite of provincial winescapes, conjoined not by its homogeneity but, paradoxically, according to its unifying multiformity.

Not everyone, however, was capable of venturing to Tuscany for the biennial vini tipici exhibition. In response, members of the IWL developed an innovative mobile extension to Siena's Exhibition Market. Inaugurated by Marescalchi on 28 October 1934 - the twelfth anniversary of fascism's March on Rome - the National Wine Truck (Autotreno nazionale del vino) was intended as a 'type of elegant itinerant shop' which offered samples of Italian wines to consumers in the piazze of 128 cities and small towns between Fiume and Taranto (Figure 7). ${ }^{109}$ Composed of two vehicles and two accompanying trailers and equipped with a 'majestic engine' by Alfa Romeo, the Autotreno constituted, in the words of The Hotel in Italy, the 'first true National Corporate Exhibition of Italian Wines'. ${ }^{110}$ Inspired by the National Grain Truck, which had campaigned throughout the peninsula between 1925 and 1930 in support of the dictatorship's Battle for Grain initiative, the Wine Truck not only promoted 'the knowledge of good wine' among Italian consumers, the vehicle's operators welcomed street level sales for bottles and flasks from passers-by. ${ }^{111}$

Much like Siena's Mostra-Mercato, the Wine Truck hoped to intensify, and further solidify, the relationship between typical winegrowers and Italian consumers. The Autotreno was 'not limited just to providing samples via servings', exclaimed one contemporary, continuing:

but in the interest of carrying out a more effective and durable propaganda, and in order to penetrate families, it distributes coupons entitling [consumers] to baskets containing [either] two bottles of sparkling wine, or two bottles of fine red wine, or two flasks of table wine, [and all] at exceptionally favourable prices. $^{112}$

Such marketing objectives would lead not only to 'a greater knowledge of our excellent oenological products', he confidently predicted, 'but also to a greater consumption'. ${ }^{113}$ Towards these objectives, the Autotreno's employees sold an accompanying three lire catalogue to any interested connoisseurs, which included descriptions of the Italian wines which were available for immediate purchase, the geographical locations of the participating wineries, helpful suggestions for storage, pairing and presentations, as well as the hours and special occasions during which specific types of Italian wines were typically consumed. ${ }^{114}$

\footnotetext{
106 Ibid.

107 Marescalchi, 'Una degna presentazione del Vino: il Padiglione emiliano alla Mostra di Siena', Enotria (Dec. 1933 ), 792.

108 Focarile, 'La Mostra Nazionale dei vini tipici a Siena', 13.

109 'L'autotreno nazionale del vino', L'Albergo in Italia (Dec. 1934), 466; 'Itinerario dell'Autotreno nazionale del vino in Italia', in Autotreno nazionale del vino: catalogo (Padova: Società Cooperativa Tipografica, 1935), 11-3.

110 'Come è stato realizzato l'Autotreno del Vino', Autotreno nazionale del vino: catalogo, 40; 'L'autotreno nazionale del vino', 468.

111 Eugenio Cacace, 'L'autotreno del vino', Il commercio vinicolo (7 July 1934), 1.

112 'L'autotreno nazionale del vino', 468. Emphasis is my own.

113 Ibid.

114 Autotreno nazionale del vino: catalogo.
} 


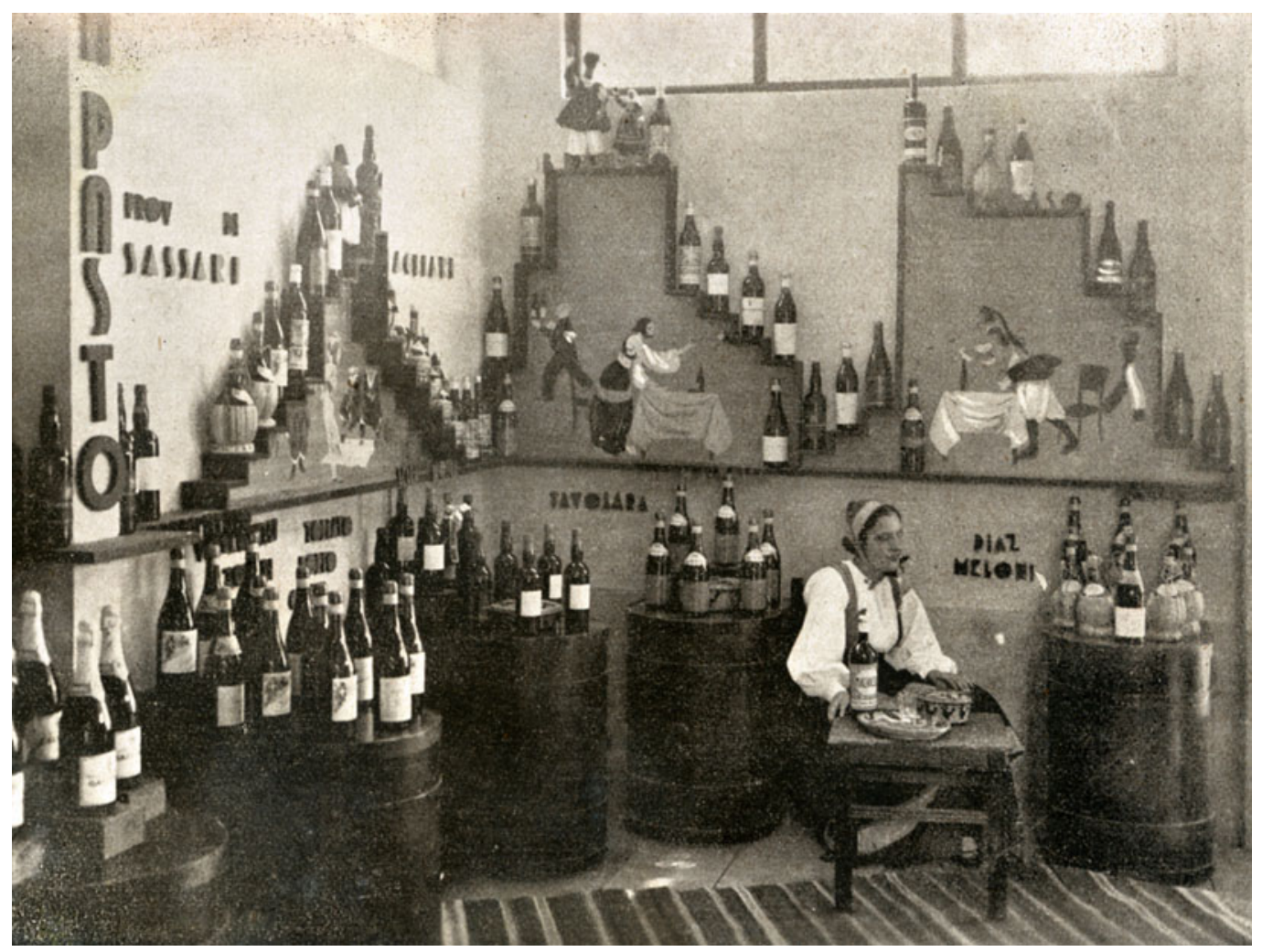

Figure 6. Bottles and Regional Heritages on Display in the Interior of Sardegna's Wine Pavillion at Siena's 1933 Exhibition Market of Typical Italian Wines

I risultati della $1^{a}$ mostra mercato vini tipici d'Italia - 3-18 agosto 1933-XI (Siena: Consiglio Provinciale dell'Economia Corporative di Siena, 1933), 57.

In addition to sampling and selling the country's typical wines in the various piazze where the Wine Truck stopped, the Autotreno was accompanied by troupes of folklorists who, much like the vini tipici exposition in Tuscany in 1933, performed 'traditional' songs and dances from Italy's principal wine growing provinces. Intended to instil an interregional wine consciousness among onlookers and paying customers alike, the National Wine Truck repositioned wine making, as well as moderate consumo di vino, as one of the unifying elements which forged Italians together as an organic, national community. By providing consumers with a gustatory panorama of the Italian peninsula, the Autotreno stimulated connoisseurs to conjure up cognitive, or sensory, maps of Italy and its regional cultures, commodities and practices and, more significantly, to recognise these interrelated resources as a national patrimony shared collectively by all Italians.

\section{Conclusion}

In contrast to the misleading and, in some cases, outright erroneous claims made by many contemporary Italian wine growers, the roots of today's 'genuine' or typical Italian wines stretch back not to antiquity or the Middle Ages but, rather, to the interwar years, during which so much of the agro-industrial and commercial foundations of modern Italian wine making, as well as Italians' enduring relationship with 'their country's' wines, were firmly established. In response to the beverage's flagging public image during the years immediately following the First World War, Italy's typical wine growers, merchants and industrialists launched a series of wide-ranging public relations and collective 


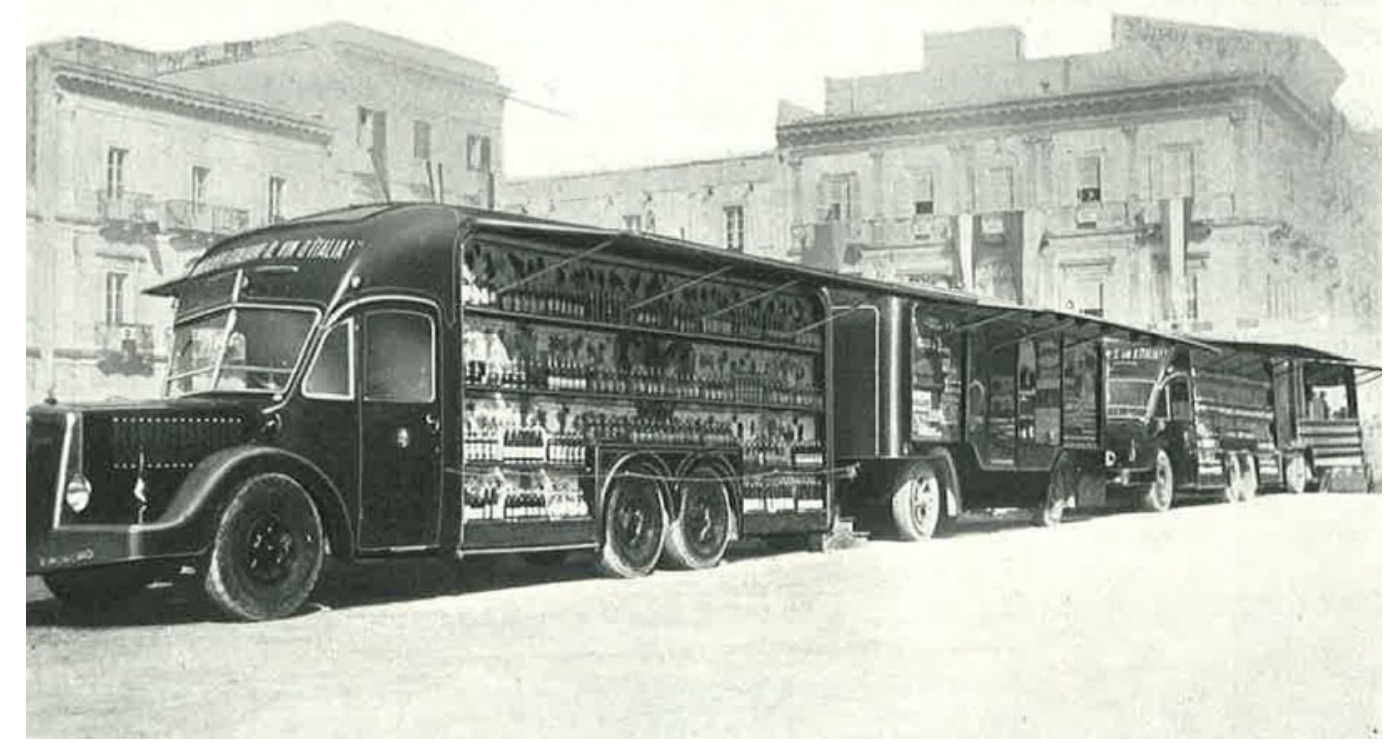

Figure 7. A Side View of the National Wine Truck Enotria (March 1935), 149.

marketing campaigns, which were intended to re-establish 'wine's honour' among the country's wayward middle and upper classes. By promoting wine's purported 'alimentary and hygienic virtues', as well as discursively intermingling the responsible, or moderate, consumption of the peninsula's vini tipici with notions of bourgeois domesticity and propriety, the IWL recontextualised vino italiano as fascist Italy's wholesome 'national beverage'. 15

The outcomes of the IWL's pro-wine campaigns, however, cannot be explained solely by commercial ingenuity alone. Indeed, wine's tumultuous journey from the peninsula's 'seedy' popular taverns and saloons to the parlours and dining tables of the country's 'respectable' households was largely facilitated by the heightened ideological climate of Mussolini's twenty year dictatorship. In co-opting and strategically manipulating the regime's politically charged vocabulary of social hygiene, popular mobilisation and 'national rebirth', fascist Italy's pro-wine lobbyists not only minimised the Italian wine making industry's commercial vulnerabilities during a period of considerable political, economic and social flux, they successfully promoted the consumption of the peninsula's luxury wines as a veritable 'national duty'. 116

The long-term socio-cultural impacts of the IWL's pro-wine campaigns, moreover, were not limited only to the years between the First and Second World Wars. As a number of scholars of modern Italy have amply demonstrated, 'the growth in the market for commercial culture between the 1930s and the 1950s laid the basis for the consumer culture associated with the economic boom of the late 1950s and early 1960s.' ${ }^{117}$ Although some of Italians' tastes 'flexed to incorporate [the] new prosperity' of the 'economic boom' years, their consumption habits - especially in regard to what they ate and drank - 'remained largely impervious to outside influences'. ${ }^{118}$ 'It is not surprising', Carol Helstosky

\footnotetext{
115 Marescalchi, Guida Gastronomica d'Italia, 4.

116 Roger Griffin, The Nature of Fascism (New York: Routledge, 1991), 182; Marescalchi, 'Ristoratori ferroviari', 1; 'Un dovere nazionale', 14.

117 David Forgacs and Stephen Gundle, Mass Culture and Italian Society from Fascism to the Cold War (Bloomington: Indiana University Press, 2007), 272.

118 Helstosky, 'Fascist Food Politics', 19.
} 
observes, reflecting on the dictatorship's impacts upon the development of a distinctly Italian cuisine, 'that the years in which food became so closely associated with the nation (and one's national allegiance) were also years during which the contours of the Italian diet and culinary tradition were solidly defined.' ${ }^{119}$ This observation is also supported by the figures for, and cultural meanings associated with, wine consumption in Italy during the post-war decades. While consumption declined from a high of 112 litres per inhabitant during the 1920s to an abysmal seventy-four following the League of Nations' economic sanctions in 1935 and, only a few years later, the ravages of the Second World War, Italians largely rekindled their relationship with the peninsula's 'millennial' beverage during the years of the so-called 'economic miracle', consuming a yearly average of some 105 litres per inhabitant between 1951 and 1970. ${ }^{120}$ The affluence and opportunity which accompanied Italy's incorporation into the Cold War era international marketplace, however, is not enough for explaining such an impressive recovery. Indeed, as this study has demonstrated, the origins of Italians' commitment to their country's wholesome, 'national beverage' had largely been manufactured during the fascist ventennio via the IWL's wide-ranging public relations and collective marketing campaigns in support of Italy's typical wines.

Acknowledgements. My research has been funded by the Council for European Studies and the Fulbright US Student Program. I would like to thank Claudio Fogu for reading and commenting on an earlier draft of this article and Kate Ferris for coordinating the St. Andrews University research colloquium on the history of food, drink and identity in modern Europe, which led to this article. I would also like to say grazie to the anonymous readers for Contemporary European History for their helpful advice and insightful suggestions.

119 Ibid.

120 'Table 3: Average Annual Per Capita Consumption of Food, 1861-2009', in Scarpellini, Food and Foodways in Italy from 1861 to the Present.

Cite this article: Griffith BJ (2020). Bacchus among the Blackshirts: Wine Making, Consumerism and Identity in Fascist Italy, 1919-1937. Contemporary European History 29, 394-415. https://doi.org/10.1017/S0960777319000377 